\title{
Using Students' L1 (Arabic) in English L2 Classrooms in College Classrooms in Kuwait
}

\author{
Abdullah M. Alazemi ${ }^{1, *}$, Ahmad F. Alnwaiem ${ }^{2} \&$ Abdullah A. Alenezi $^{1}$ \\ ${ }^{1}$ Language Center, The Public Authority for Applied Education and Training, Kuwait \\ ${ }^{2}$ Department of Curriculum and Instruction, College of Basic Education, The Public Authority for Applied Education \\ and Training, Kuwait \\ *Correspondence: Language Center, The Public Authority for Applied Education and Training, Kuwait. E-mail: \\ amd.alazmi@paaet.edu.kw
}

Received: June 15, 2021

Accepted: July 11, $2021 \quad$ Online Published: July 19, 2021

doi:10.5430/ijelt.v8n2p1

URL: https://doi.org/10.5430/ijelt.v8n2p1

\begin{abstract}
This study explored the use of students' L1 (Arabic) in one of Kuwait's public institutions - namely, the Public Authority for Applied Education and Training (PAAET). The purpose of this study was three-fold: (1) to look at the functions of using L1, (2) to explore any comprehensibility issues and/or academic gains, and (3) to investigate any psychological issues students face when not using L1. The study employed a two-stage data collection phase, where a total of 278 students participated in the closed-ended questionnaire and 6 students participated in the semi-structured interviews. The results showed that students attach several important aspects to the use of L1 in their L2 classrooms. Students expressed that the inclusion of Arabic eases their intake from lectures and allows them to better understand the lectures' content. However, the findings also indicated that students object to the overreliance on Arabic and instead prefer that teachers strike a balance between L1 and L2 use to maximize their learning.
\end{abstract}

Keywords: L1 (Arabic), L2 (English), ELT, English teaching

\section{Introduction}

The inclusion of students' native language and its influence on L2 learning has been debated for a few decades by teachers, linguists, and researchers. This has been a controversial area as different arguments, and second language theories have proposed different hypotheses and rationales regarding the effectiveness of L1 in L2 classrooms (Kalanzadeh et al., 2013). Some researchers and educationalists have argued that the use of L1 in teaching L2 could obstruct students' progress in learning the L2, while less use of L1 would mean more exposure to L2 (Cook, 2013; Krashen, 1985). Proponents of only using L2 argue that using L1 in the classroom could deny students the appropriate exposure to L2 contexts, thereby having detrimental consequences (Turnbull, 2001; Ellis, 2008). On the other hand, others have argued that a well-planned use of L1 could lead to better learning experiences and outcomes (Nilubol, 2020).

Furthermore, some critical applied linguistics have stated that political and social reasons are behind the prevailing fallacy that the complete use of L2 on its own would lead to better learning outcomes (Pennycook, 2001; Phillipson, 2009). Phillipson (2009), for example, has argued that proposing the notion of only using English in L2 classrooms is an imperialistic approach that emphasizes the prominence of English at the expense of devaluing the L1.

These polarized opinions on the value of including L1 in L2 classrooms have presented rich, but yet opposing literature. However, studies have found that, when the teacher shares the same L1 and background with the students, they tend to use it alongside the L2 (Rabbidge \& Chapell, 2014). Empirical research has shown that using L1 in a well-planned way could result in benefiting students' grammatical acquisition (Vaezi \& Mirzaei, 2007) and their vocabulary acquisition (Liu, 2008). L1 use advocates do not dismiss the importance of L2 exposure to students' learning experiences; however, they recommend reasonable use of L1 in classrooms to promote a better learning environment and ease certain teaching aspects. Cook (2013) has showed that L1 could be used to explain difficult 
lexical words and grammatical rules, build rapport, maintain discipline, organize tasks, check for comprehension, and give instructions.

\section{Literature Review}

\subsection{L1 as a Tool}

The current body of research has highlighted the important role of L1 in L2 classrooms and the many possible benefits it presents (Azkarai \& Mayo, 2016). This is in contradiction to the L2-only policy frequently advocated by policymakers, which overshadows the positive effects of L1 use in L2 classrooms (Mohebbi \& Alavi, 2014). For example, Norman (2008) argued that students are unwilling, inattentive, and sometimes unresponsive in classrooms. However, he observed that the opposite happens with the same students when L1 is occasionally used. Such research reflects the importance of including L1; when implemented correctly, it could result in several benefits for both students and teachers. Teachers could resort to L1 in order to ease certain aspects of instruction delivery and allow their students to use L1 to cause them less embarrassment (Meyer, 2008). Prohibiting students from using L1 as a tool could result in an unhappy environment for them (Burden, 2001). Some scholars have argued that the careful use of L1 could assist students in making higher cognitive adjustments while learning a language, and it could be useful in anticipating, correcting, and recognizing any blurs by comparing both languages (Brown, 2015).

Although L1 could serve as a beneficial learning tool, the extent of its inclusion determines whether it is helpful or detrimental (Stephens, 2006). L1 could serve as a vital learning tool to compare between both languages when accuracy is needed and time is limited (Mohebbi \& Alavi, 2014). With this being said, there is no single model or perfect balance; it must be determined as appropriate to students' ways and times (Nation, 2003). As Zulfikar (2018) suggested, monolingual classrooms sometimes lead to communication breakdowns and much confusion when teachers adhere to strict L2-only policies. This is applicable in many incidents when students need to understand a word but feel reprimanded for using their L1, so rather than asking for more clarification, they resort to being silent. However, as Burden (2001) illustrated, when students are allowed to use L1 they may be more secure in expressing themselves, which in turn allows teachers to analyze students' learning achievement and determine if they need further assistance.

\subsection{Stimulating Collaborative Dialogue}

Swain (2000) explained that collaborative dialogue occurs when students respond to and produce utterances as they work with their colleagues to accomplish learning tasks. In collaborative dialogue, students engage in classroom discussions and exchange information with their teachers or partners in order to gain new knowledge, clarify meaning, and/or develop understanding of the course content. In this interaction, students are able to compare and contrast their ideas in a familiar linguistic context to develop a better understanding of L2. L1 functions as a means for students to stimulate information exchange and further interaction that leads to a better mastery of L2 (Zulfikar, 2018). Giving students the freedom to resort to their L1 when they need more clarity or become stuck on a certain concept will provide them with another option to learn what is needed of them. Ultimately, this breaks the barriers of many psychological obstacles that obstruct students' participation during lectures, such as feeling embarrassed in not being able to ask or express their ideas or even to respond with the appropriate language in L2 (Cook, 2013). This was evident in a study of the role of L1 Spanish and French in L2 classrooms (Scott \& Fuente, 2008), in which the researchers noted that there was continuous interaction, fewer pauses, ample evidence of collaborative dialogue, and balanced contribution to interaction in classrooms that allowed L1 use. Furthermore, Alrabah et al. (2016) illustrated that Kuwaiti teachers found students refrained from participating and felt anxious, fearful, and sometimes frustrated when they were not able to follow what the teacher was saying in L2. Such psychological factors could harm students' learning possibilities and have a detrimental effect on their understanding of the course content. As Copland and Neokleous (2011) stated, "decisions about when to use L1 and L2 are complex and seem to be based on both affective and cognitive factors" (p. 6).

\subsection{English Teaching in Kuwait}

English has been taught in Kuwait for nearly a century (Alazemi, 2020); however, it was not taught officially in public schools until the 1960s. By that time, it was only taught in the intermediate and secondary stages. Later in 1994, through the Kuwaiti parliament, English was introduced as a core subject to students from the primary stage, so it was taught to students from age 6 to 18 years old. This established a greater emphasis on the importance of English, and it was believed that it would result in students' better attainment in English after graduating from school and embarking on their journey at the tertiary level. However, several studies have shown that such a step does not 
fulfill the preset learning targets (Alazemi, 2020), as there was an evident gap of knowledge between students' level of English upon graduation and what Kuwaiti colleges and universities required. Furthermore, Alotaibi et al. (2014) found that only $21 \%$ of students applying to the Public Authority for Applied Education and Training (PAAET), one of Kuwait's public tertiary institutions, passed the placement test required to enter certain colleges. The colleges in PAAET implemented more advanced English remedial classes in order to allow students to cope with the required level of English. Another study (Al-Bustan \& Al-Bustan, 2009) conducted at Kuwait University showed how students felt frustrated that the level of English they achieved in school did not meet the necessary demands, thereby resulting in some students not being able to continue their chosen majors. Such findings from both institutions could be one of the major reasons why more Arabic is used in EFL classrooms. Such a rationale was presented and supported by another study done in Kuwait (Alrabah et al., 2016), which investigated the reasons why some EFL teachers resorted to using Arabic in their lectures. The study found that, although most teachers had negative perceptions of using Arabic in class, they still used it for many purposes in order to help students out and make some instructions clear.

\section{Methodology}

\subsection{Research Questions}

This study aimed to answer three questions relating to the use of L1 in L2 classrooms:

1) What are the functions that PAAET students related to the use of L1?

2) What are the comprehensibility issues and/or academic gains?

3) Do students face any psychological issues when not using L1?

\subsection{Setting}

Data were collected from students from the five colleges at PAAET. One of the objectives of this tertiary institution is to equip students with a good command of English; therefore, students in all different majors need to take a minimum of three English for specific purposes (ESP) courses. These courses are offered to students who major in a range of fields, such as medicine, banking, engineering, science, and education. During the admission process, students need to sit for a placement test where they need to attain a minimum score of $60 \%$. However, if they fail to do so, they need to attend an extra remedial course to improve the proficiency level.

\subsection{Participants}

A total of 278 participants agreed to take part in the study. All the necessary approvals were attainted from both institutions' relevant colleges and departments. Participants were notified of their right to withdraw from the study at any time they wished and that they could dismiss any question they did not feel comfortable answering. The students were from different colleges, majors, and year levels and included both males and females.

\subsection{Data Collection}

Data were collected in two phases, following a sequential mixed-method approach. The first phase involved a closed-ended questionnaire with 278 respondents whom were randomly selected, and a pilot study was conducted including 2 specialists that provided feedback concerning word structure and rephraizing, before the finaliazed version was distributed. In the second phase, six students took part in the semi-structured interviews, and participants were selected based on the criteria that they completed the questionnaire and were willing to take part in the interviews.

Interviews were conducted in Arabic so students were able to express themselves better. The purpose of such an approach, which involved two different data collection methods, was to strengthen the findings and allow the findings to support each other to find a better outcome (Bryman, 2012). Furthermore, such an approach helped gather ample information in the first stage and focus on certain aspects in the second stage (Dornyei, 2007).

\section{Results}

The study had three aims: (1) to look at the functions of using L1, (2) to explore any comprehensibility issues and/or academic gains, and (3) to investigate any psychological issues students face when not using L1. In order to determine students' views on the use of L1, the researchers examined all the results from both interviews and 
questionnaires. The results of this aim were divided into three sub-categories: functions of L1, comprehensibility and academic gain, and psychological aspects.

\subsection{Functions of $L 1$}

The results indicated that students attached several functions to using L1 in their classrooms, as they expressed their views on certain patterns for the inclusion of L1 use in teaching English, as shown in Table 1.

Table 1. Functions of L1 in L2 Classrooms

\begin{tabular}{|c|c|c|c|}
\hline \multirow{2}{*}{ Inclusion of L1 } & \multicolumn{3}{|c|}{ Item Responses } \\
\hline & Agree & Not Sure & Disagree \\
\hline $\begin{array}{l}\text { 1. I prefer that the course professor uses a mixture of Arabic and English in } \\
\text { the lecture to explain the lessons }\end{array}$ & $79 \%$ & $11 \%$ & $10 \%$ \\
\hline $\begin{array}{l}\text { 2. I prefer that the course professor translates the English word into Arabic } \\
\text { instead of explaining it in English }\end{array}$ & $66 \%$ & $10 \%$ & $24 \%$ \\
\hline $\begin{array}{l}\text { 3. I prefer that the course professor explains the grammar rule only in Arabic } \\
\text { instead of in English }\end{array}$ & $43 \%$ & $18 \%$ & $39 \%$ \\
\hline $\begin{array}{l}\text { 4. It is preferable for the course instructor to compare grammar in English } \\
\text { with its equivalent in Arabic }\end{array}$ & $57 \%$ & $14 \%$ & $29 \%$ \\
\hline $\begin{array}{l}\text { 5. I prefer the course teacher to explain my mistakes in Arabic so that I can } \\
\text { understand them better }\end{array}$ & $83 \%$ & $9 \%$ & $8 \%$ \\
\hline $\begin{array}{l}\text { 6. I prefer that the professor of the English language course allows the } \\
\text { students to answer his/her questions in Arabic sometimes }\end{array}$ & $65 \%$ & $12 \%$ & $23 \%$ \\
\hline
\end{tabular}

The students in this section were asked to express their views on certain aspects regarding the inclusion of Arabic in their teaching/learning during their English courses and the degree of that inclusion. As seen from the results of Item 1, the majority of students (79\%) agreed to the use of Arabic during their English courses, while $10 \%$ disagreed and $11 \%$ were not sure. Furthermore, the other items aimed to elicit students' views in more detailed aspects of the inclusion of Arabic. For example, in Item 2, 66\% of the respondents indicated that they preferred teachers to translate English words into Arabic rather than explaining them in English. This seems to be an easier option for them to understand the meanings, as it could be more practical for them. This was also echoed in the interviews by all students, as Aziz said:

It will be easier for us to just say the Arabic counterpart of the word we are learning instead of the teacher trying to use more English. Many of us are not good at English, so explaining it in English will make it will make it more difficult.

However, in Item 3, when students were asked if they preferred teachers to use only Arabic when explaining grammar, the agreement percentage dropped to $43 \%$ while $18 \%$ did not know and $39 \%$ disagreed. Thus, students recognized the need to learn through English and that a complete shift to Arabic is not beneficial. Furthermore, 18\% were not sure, which could be because they were not confident that such a step would be useful and were not sure what was in their best interest. However, when students were asked (Item 4) if their teachers should compare English grammar to its counterpart in Arabic, the percentage of agreement rose to 57\%, while 29\% disagreed and 14\% were not sure. Students might believe that comparing the two languages helps their understanding. This was also the case in the interviews, as Sara explained:

I already know the Arabic grammar well enough, so when the teacher compares [the two grammars], I can easily connect the rules and I will be able to understand it quicker.

Some students were cautious about how much English is implemented, as Khaled explained:

Yes, I do want the teacher to compare both languages, but I still need to understand the grammar in English. So teachers should initially explain and compare in Arabic, then use only English to continue the instruction.

Thus, although some students preferred the inclusion of Arabic, they were still careful about how much should be included. They recognized the importance of grasping the grammatical rules in their context. 
The final two items in this section focused on coursework explanations and asking questions in classrooms. The data indicated that $83 \%$ of the respondents preferred for their teachers to explain their mistakes to them in Arabic rather than English, and only $8 \%$ disagreed while $9 \%$ were not sure. This high percentage shows that students wanted to make sure they understood their mistakes to work on them; doing so in English might not benefit them in the same way. On the other hand, for Item 6,65\% agreed that their teachers should allow them to ask questions in Arabic from time to time, although $23 \%$ disagreed and $12 \%$ were not sure. A similar research conducted in Germany (De La Campa \& Nassaji, 2009) also found that $62 \%$ of teachers allowed students to ask questions using L1. Furthermore, some students in the interviews were very explicit about this. As Lulu stated:

If I make a mistake in English and I am still learning that language, then it will surely be better to understand what I did wrong, and what better way to get it explained than in my mother tongue!

\subsection{Comprehensibility and Academic Gain}

The second sub-category of the questionnaire focused on students' comprehensibility and academic gain. The items in Table 2 reflect the comprehension issues students face in L2 classrooms and if using their L1 could help facilitate their learning experience.

Table 2. Comprehensibility and Academic Gain

\begin{tabular}{llll}
\hline \multirow{2}{*}{ Comprehensibility and Academic Gain } & \multicolumn{3}{c}{ Item Responses } \\
\cline { 2 - 4 } & Agree & Not Sure & Disagree \\
\hline $\begin{array}{l}\text { 1. The use of Arabic by the teacher in his/her instruction helps me } \\
\text { understand better }\end{array}$ & $81 \%$ & $9 \%$ & $10 \%$ \\
$\begin{array}{l}\text { 2. I prefer for the course teacher to answer my questions in Arabic to help } \\
\text { me understand the answer better }\end{array}$ & $66 \%$ & $18 \%$ & $16 \% \%$ \\
$\begin{array}{l}\text { 3. The use of Arabic by the teacher in his/her explanation helps improve my } \\
\text { grades in the course }\end{array}$ & $77 \%$ & $13 \%$ & $10 \%$ \\
$\begin{array}{l}\text { 4. Sometimes I have to review the lessons after the lecture (in which only } \\
\text { English is used) to better understand the content of the lecture }\end{array}$ & $70 \%$ & $14 \%$ & $16 \%$ \\
5. I usually find it difficult to ask questions in English during the lecture & $61 \%$ & $15 \%$ & $24 \%$ \\
\hline
\end{tabular}

The findings show that comprehensibility issues during English language courses are reoccurring and cause problems for many students. Indeed, $81 \%$ of the respondents agreed that using Arabic during teachers' instruction allows them to better understand the lectures, although $9 \%$ were not sure and $10 \%$ disagreed. This high percentage shows that a large number of students are not benefitting as expected from the lectures. This point was confirmed by Item 4 , as $70 \%$ of the students need to review and revise what is said in the lectures in order to get a better understanding (16\% disagreed and $14 \%$ were not sure). This point was also raised by many interviewees, such as Maha:

We are after all Arabs, and nearly all of our schooling, as well as our daily lives, are conducted in Arabic. By shifting quickly to English in our English courses at our colleges, this causes more trouble. We have groups where we help each other and those who understood explain to the rest what has been said during the lectures.

As Maha explained, many students organize groups to help each other and review the information shared during the lectures.

Furthermore, in Item 2, the majority of students $(66 \%)$ agreed that they preferred teachers to answer their questions in Arabic, while 16\% disagreed and 18\% were not sure. It seems that students want to make sure they understand the answers to their questions. According to Saleh:

Usually when I have a question, I have difficulty in how to ask and cannot easily put the words together, so if the teacher answers in English, this could cause more understanding issues. Therefore, it will be more straightforward if the teacher just explained it in a language I already know $100 \%$.

Saleh, as well as others, explained how answering in Arabic could make the learning process easier and more straightforward. In Item 5, students indicated that it is difficult to formulate questions in English (61\% agreed, 24\% 
disagreed, and $15 \%$ were not sure), and answering them in complete English could result in complicating the matter, thereby leading to deeper comprehensibility issues. The $24 \%$ of respondents who did not have problems asking questions in English might already have a good command of English and/or be graduates of private English schools.

Students were also asked, in Item 3, if they believed that using more Arabic could improve their grades; $77 \%$ agreed, $10 \%$ agreed, and $13 \%$ were not sure. This is an important point, as doing good in their courses means they will attain better GPAs, which would lead to better career prospects. This could lead to psychological issues, as discussed in the next section.

\subsection{Psychological Aspects}

The final sub-category focused on the mental and psychological aspects of the learner. It was intended to elicit any psychological issues the learners might face.

Table 3. Psychological Aspects

\begin{tabular}{|c|c|c|c|}
\hline \multirow{2}{*}{ Psychological Aspects } & \multicolumn{3}{|c|}{ Item Responses } \\
\hline & Agree & Not Sure & Disagree \\
\hline 1. Lectures in English make me nervous during the lecture & $48 \%$ & $18 \%$ & $34 \%$ \\
\hline $\begin{array}{l}\text { 2. Sometimes I avoid participating in lectures in which the language of } \\
\text { instruction is English because I find it difficult to convey my idea of the } \\
\text { answer }\end{array}$ & $58 \%$ & $9 \%$ & $33 \%$ \\
\hline $\begin{array}{l}\text { 3. Sometimes I turn to my colleagues, which embarrasses me sometimes, to } \\
\text { explain or clarify what was mentioned in the lecture if it is in English only }\end{array}$ & $65 \%$ & $12 \%$ & $23 \%$ \\
\hline $\begin{array}{l}\text { 4. I feel more comfortable when the teacher allows us to speak with him/her } \\
\text { in Arabic (such as asking questions, answering them, inquiring) }\end{array}$ & $83 \%$ & $10 \%$ & $7 \%$ \\
\hline
\end{tabular}

Although the majority of students agreed that lectures delivered only in English make them more nervous during the lectures (i.e., Item 1), 34\% disagreed and $18 \%$ were not sure. This could leave many students not participating during lectures, which was the purpose of Item 2, with which 58\% agreed, 9\% were not sure, and 33\% disagreed. These 2 items were also discussed in the interviews by several participants. As Aziz explained:

\section{I hesitate a lot during lectures where only English is allowed. I feel afraid of not being able to convey my idea, and this causes embarrassment. I prefer to be quiet rather than trying to take a long time to explain what I mean.}

Students were also asked in Item 3 if they feel embarrassed if they had to ask their colleagues for explanations about something said in the lecture; $65 \%$ agreed, $23 \%$ disagreed, and $12 \%$ were not sure. This seems to cause more pressure on students, and this embarrassment could also lead them to not ask at all.

Finally, $83 \%$ of students agreed to Item 4 , as they feel more comfortable when the teacher allows them to speak in Arabic with them. This vast majority shows how Arabic could ease a lot of issues during lectures. As Lulu explained:

When I am allowed to use Arabic, I feel relieved, and this allows me to engage more and even ask any question that comes across my mind. Sometimes, when only English is allowed, I just look for the answer afterwards or ask one of my colleagues.

Lulu raised an important issue, as some students would not ask teachers for clarification and would prefer to ask colleagues later or even search for the answer themselves.

\section{Discussion}

The results of the study show the importance of using L1 in L2 classrooms to students in PAAET's colleges. This importance was considered in three sections that were the focus of the research questions. In terms of the first question, pertaining to the functions of L1, students attached several important functions that they believed could ease their learning experiences. The results indicated that the majority of students preferred for their teachers to use a mixture of Arabic and English in order to make the instruction delivered in class accessible. Students believed that allowing them to use Arabic in class and/or teachers using Arabic to explain grammar or students' mistakes would improve their learning. This finding supports the results of a study conducted in Iran (Mohebbi \& Alavi, 2014), whereby more than $80 \%$ of the participants preferred translating English terms into Persian when teaching new 
vocabulary. Thus, students, as well as teachers, implement the translation of new vocabulary for ease of understanding.

The second research question focused on comprehensibility issues and academic gains. The results reflected that using more Arabic, or at least its inclusion in certain aspects of the lecture, would help resolve several comprehension issues. Students indicated that they had problems understanding lectures delivered only in English, and some had to revise and revisit what had been discussed in class. This issue could cause an information gap as students miss aspects of their lectures. Thus, lectures become more of a burden than an important source of information (Alazemi, 2020). If students go to lectures and find themselves in deeper confusion, lectures could become more of an obstacle. Similar research has shown the same findings. For example, in Slovakia, Hanakova \& Metruk (2017) found that students frequently asked teachers to provide them with a translation of new vocabulary in their L1 as it helped them learn the word quicker, and students resorted to asking questions in L1 and preferred teachers to also respond in L1 because it allowed them to better understand the answers to their questions.

Furthermore, based on the results of this study, students believed that including more Arabic in the lecture instruction, exams, and other aspects would allow them to attain higher grades. They seemed to link the inclusion of L1 to improving their grades because L1 helps them understand the content of the lecture, which leads to an ultimate understanding of the course content, thereby allowing them to perform better during exams and tests (Zulfikar, 2018). This shows the importance of the inclusion of L1 and academic gain to students, who relate L1 not only to better understanding but also to gaining better scores and how it affects their career prospects in the future.

The third and final research question was concerned with psychological aspects. This is also an important issue to consider as a vital part of students' learning is their psychological readiness; when they are relaxed and comfortable, they generally enhance their performance. The results showed that students preferred teachers to allow them to ask, answer, and/or raise questions in Arabic; if they are not able to do so, they would refrain from asking questions in class to avoid embarrassment. Students would rather refrain from participating if only English is allowed because they find it difficult to express their ideas. Encouraging students to participate is a vital aspect of their learning experience, as it allows them to become active learners rather than passive learners (Liu, 2001). Cheng (2013) also found that including L1 in a balanced manner reduces students' stress and anxiety in the classroom.

The findings of this study, which are in line with the previous literature, support the notion of the importance of using L1 in L2 classrooms. However, the inclusion of L1 must be balanced so as not to affect students' intake of English. It seems that students attach several aspects to using L1, ranging from functions to comprehensibility, academic gain, and psychological factors. It must be noted that, in many cases, students graduating from Kuwait's public high schools do not have the relevant command of English that universities and colleges require. Thus, the complete reliance on L2 could become more of a burden and hindrance, rather than a positive source of information.

\section{Implications and Future Research}

Several studies have shown that, in many EFL classrooms, teachers use L1 for more than $40 \%$ of the classroom speaking time (e.g., Rabbidge \& Chapell, 2014). This study calls for better teaching strategies whereby the inclusion of L1 is balanced during classrooms to harbor a productive learning environment for students. One of the implications is for teacher training programs to train teachers with the necessary teaching techniques and strategies to harness the use of L1 in their classrooms. This would allow teachers to provide a productive learning environment. Furthermore, by considering the psychological and comprehensibility issues, teachers should allow and encourage students to use L1 in certain aspects of the lesson. This would encourage students to become active learners; ultimately, having students asking questions in L1 is more constructive than having them be quiet for most of the lessons. A final implication is that teachers ought to take into consideration students' psychological issues.

More research is needed to delve into this phenomenon, as it includes several essential topics that could lead to a positive teaching/learning outcome. There is a need to explore the probable link between using L1 and students' class performance. We could not simply overlook if using L1 could allow students to attain better grades, which consequently affects their career prospects. Finally, it would be wise to research and understand how, and to what degree, the inclusion of L1 would benefit students and what appropriate strategies and techniques could ensure that outcome. 


\section{Conclusion}

This study explored Kuwaiti students' views on the use of L1 in L2 classrooms in the PAAET's colleges in Kuwait. The findings clearly show that the majority of students approve of the use of L1 in their L2 classrooms for several functions, comprehensibility, and academic gains. The findings also show that L1 use could help resolve several psychological obstacles that could hinder their learning possibilities. Nevertheless, the findings of this study should be considered with caution as further research needs to be conducted in this area. Most research conducted in Kuwait regarding L1 use in L2 classrooms has focused mainly on teachers and policymakers; therefore, this research has presented a new dimension to the ever-debated topic.

The findings of this research, as well as research from around the globe, confirm the importance of L1 use in L2 classrooms and that the benefits of L1 could facilitate teaching and learning experiences. It should be noted that L1 could serve as a positive learning tool that helps maximize students' understanding of the course content. L1 should not be regarded as an obstruction in L2 classrooms, but rather as a facilitator and a necessary means by which to help with the learning process.

\section{References}

Alazemi, A. (2020) The effect of the policy of English as medium of instruction on Arabic in Kuwait. In Troudi S. (Ed.), Critical Issues in Teaching English and Language Education. Palgrave Macmillan, Cham. https://doi.org/10.1007/978-3-030-53297-0_3

Al-Bustan, S. A., \& Al-Bustan, L. (2009). Investigating students' attitudes and preferences towards learning English at Kuwait University. College Student Journal, 43(2), 454-463.

Alotaibi, A., Aldiahani, H., \& Alrabah, S. (2014). An investigation of the factors which contribute to low English achievement in secondary schools, as perceived by Kuwaiti and non-Kuwaiti English teachers. European Scientific Journal, 10(25), 440-459.

Alrabah, S., Shu-Hua, W., Alotaibi, A., \& Aldaihani, H. (2016). English Teachers' Use of Learners' L1 (Arabic) in College Classrooms in Kuwait. English Language Teaching, 9(1), 1-11.

Azkarai, A., \& May, M. (2016). Task repetition effects on L1 use in EFL child task-based interaction. Language Teaching Research, 21(4), 480-495.

Brown, D. (2015). Teaching by Principles: An interactive approach to language pedagogy (4th ed.). NY: Pearson Education.

Burden, P. (2001). When do Native English Speakers and Japanese College Students Disagree about the Use of Japanese in the English Conversation Classroom? The Language Teacher, 25(4), 5-10.

Cheng, T. P. (2013). Codeswitching and participant orientations in a Chinese as a foreign language classroom. The Modern Language Journal, 97(4), 869-886.

Cook, V. (2013). Second language learning and language teaching (4th ed.). New York: Routledge.

Copland, F., \& Neokleous, G. (2011). L1 to teach L2: Complexities and contradictions. ELT Journal, 65(3), 270-280. http://dx.doi.org/10.1093/elt/ccq047

De la Campa, J., \& Nassaji, H. (2009). The amount, purpose, and reasons for using L1 in L2 classroom. Foreign Language Annals, 42(4), 742-759. http://dx.doi.org/10.1111/j.1944-9720.2009.01052.x

Dornyei, Z. (2007). Research Methods in Applied Linguistics. Oxford: Oxford University Press.

Ellis, R. (2008). The Study of Second Language Acquisition. Oxford: Oxford University Press.

Hanakova, M., \& Metruk, R. (2017). The use of L1 in the process of teaching English. Modern Journal of Language Teaching Methods, 7(8), 208-216.

Kalanzadeh, G. H. K., Hemati, F., Shahivand, Z., \& Bakhtiarvand, M. (2013). The Use of EFL students' L1 in English classes. The International Journal of Language Learning and Applied Linguistics Word, 2(2), 30-39.

Krashen, S. D. (1985). The input hypothesis: Issues and implications. New York: Addison Wesley Longman Ltd.

Liu, J. (2008). L1 use in L2 vocabulary learning: Facilitator or barrier. International Education Studies, 1(2), 65-69. http://dx.doi.org/10.5539/ies.v1n2p65

Meyer, H. (2008). The pedagogical implications of L1 use in the L2 classroom. Maebashi Kyoai Gakuen College 
Ronsyu, 8, 147-159.

Mohebbi, H., \& Alavi, M. (2014). An Investigation into Teachers' First Language Use in a Second Language Learning Classroom Context: A Questionnaire-based Study. Bellaterra Journal of Teaching \& Learning Language \& Literature, 7(4), 57-73.

Nation, P. (2003). The role of the first language in foreign language learning. The Asian EFL Journal, 5(2), 1-8.

Nilubol, K. (2020). The impacts of L1 integration towards general English classroom of Thai public university undergraduate students: An account of learning motivation perspective. Language Education and Acquisition Research Network Journal, 13(2), 426-444.

Pennycook, A. (2001). Critical applied linguistics: A critical introduction. Mahwah, NJ: Lawrence Erlbaum.

Phillipson, R. (2009). Linguistic imperialism continued. New York, NY: Routledge.

Rabbidge, M., \& Chapell, P. (2014). Exploring non-native English speaking teachers' classroom language use in South Korean elementary schools. TESL-EJ, 17(4), 1-18.

Scott, V. M., \& Fuente, M. J. (2008). What's the problem? L2 learner's use of the L1 during consciousness-raising, form-focused tasks. The Modern Language Journal, 92(1), 100-113. http://dx.doi.org/10.1111/j.1540-4781.2008.00689.x

Stephens, M. (2006). The use and abuse of Japanese in the English university class. The Language Teacher, 30(8), 13-17.

Swain, M. (2000). The output hypothesis and beyond: Mediating acquisition through collaborative dialogue. In J. P. Lantolf (Ed.), Sociocultural theory and second language learning. Oxford, England: Oxford University Press.

Turnbull, M. (2001). There is a role for the L1 in foreign and second language teaching, but... Canadian Modern Language Review, 57(4), 531-540. http://dx.doi.org/10.3138/cmlr.57.4.531

Vaezi, S., \& Mirzaei, M. (2007). The effect of using translation from L1 to L2 as a teaching technique on the improvement of EFL learners' linguistic accuracy - focus on form. Humanizing Language Teaching, 9(5).

Zulfikar, Z. (2018). Rethinking the use of L1 in L2 classroom. Englisia, 6(1), 43-51.

\section{Copyrights}

Copyright for this article is retained by the author(s), with first publication rights granted to the journal.

This is an open-access article distributed under the terms and conditions of the Creative Commons Attribution license (http://creativecommons.org/licenses/by/4.0/). 